\title{
Magyar és német tapasztalatok a xenofóbia terén ${ }^{1}$
}

\section{Hungarian and German Experiences in Xenophobia}

\section{Összefoglalás}

Az írás azon problémák egyikével foglalkozik, amelyeket az európai társadalmakban a 20. század elején megindult s jelenleg is zajló migráció, valamint a 20. század második felében hangsúlyt kapott integráció kérdései vetettek fel. Nevezetesen azzal, hogy a különbözó kulturális és nemzeti háttérrel rendelkezô csoportok együttélése esetén a különbözô társadalmak és államok miként kezelik a kialakuló nyíltan xenofób cselekményeket. Ennek keretében elsôsorban Magyarország és Németország vonatkozásában áttekintést ad az idegenellenes jelenségekrôl, kiváltó okaikról és lehetséges kezelésmódjaik elemzésérôl. Miközben összefoglalja a magyar és német szakirodalmat, egy késôbbi kutatás kiindulópontjait is megfogalmazza, kitér az ún. „gyúlölet-búncselekmények” és „gyúlöletincidensek” problémájára is.

Kulcsszavak: migráció, idegenellenesség, szélsőjobboldaliság, jogalkotás

\section{Summary}

The article deals with one of the problems raised by the migration that started in European societies in the early 20th century and is still ongoing, and by integration, emphasized in the second half of the 20th century. The question how different

GulYás Éva PhD-hallgató, Nemzeti Közszolgálati Egyetem Közigazgatástudományi Doktori Iskola (Gulyas.Eva@uni-nke.hu). 
societies and states handle the evolving openly xenophobic acts in the case of a coexistence of groups with different cultural and national backgrounds is addressed. In this context, the article provides an overview of xenophobic phenomena, their causes, and an analysis of the possible methods of handling them, with particular attention to Hungary and Germany. While it summarizes the relevant Hungarian and German literature, it also drafts the starting points of a future research, and also discusses the problem of "hate crimes" and "hate incidents".

Keywords: migration, xenophobia, extreme rightness, legislation

A 20. század második felében Európa népessége sokszínúvé vált: részben a hagyományosan európainak tekintett nemzetek és népek keveredtek egymással az európai integráció közismert viszonyai között, de különbözô okokból, nagy számban megjelentek és tartósan letelepedtek itt az Európán kívüli népek, etnikumok és csoportok is. A század utolsó évtizedeire kiderült, hogy az utóbbi csoportok integrációja állami támogatással sem valósult meg teljesen, miközben a globalizáció által okozott és a világpolitikai-nagyhatalmi összefüggések keretében keletkezett problémák okán elôállt bevándorlás miatt további integrációs feszültségek keletkeztek.

Bárhogy is foglaljunk állást a multikulturalizmus és a népességmozgás vitatott kérdéseiben, tény, hogy a 20. század elején a globalizáció és más világpolitikai összefüggések miatt megindult és más okok miatt ma is tartó migráció, valamint a 20. század második felében teret nyeró integráció az európai társadalmakban több problémához is vezetett. ${ }^{2}$ Ezek egyike az idegenellenesség, mely számos országban - így Franciaországban, Norvégiában, Dániában, Németországban, Ausztriában, Magyarországon stb. - különbözó devianciákhoz vezetett. A xenofóbia a különbözó társadalmakban különbözô módon nyilvánul meg, de mára már-már megszokottá váltak azok a híradások, amelyek az európai országokban elkövetett nyíltan xenofób, rendszerint jogellenes cselekményekról tájékoztatnak. Ezeket a 2015/16-os év bevándorlási hulláma csak felerôsítette, és sporadikus jelleggel kölcsönössé tette. Ez utóbbi fordulat azt jelenti, hogy az „idegenekkel” és a bevándorlókkal szembeni xenofób cselekedetekre alkalmilag a bevándorlók is hasonló, a béke és az erôszak határán mozgó jogellenes cselekményekkel válaszolnak. Bár a xenofóbia nemzetközi jelenség, Magyarország és Németország e tekintetben számos egyedi sajátossággal rendelkezik.

Egy ennél konkrétabb megállapításhoz mindenekeloott olyan kutatást kell lefolytatni, amelynek célja - általában - a nyíltan xenofób jelenségek, kiváltó okaik, lehetséges kezelésmódjaik elemzése, ezek migrációval való összefüggésének vizsgálata európai kontextusban; konkrét célja pedig a német tapasztalatok összegyújtése, valamint az állami és közigazgatási problémakezelés német és magyar eszközrendszerének összehasonlítása. Ez részben adatgyújtést jelentene, részben pedig a folyamatok elemzését, a változások megállapítását, valamint az idegengyúlölettel kapcsolatos társadalmi és állami reakciók összehasonlítását igényli a két államon belül. 
A témára vonatkozó német elemzések köréből mindenekelôtt Hermann Kurthen, Werner Bergmann és Rainer Erb elmélete túnik hasznosnak. ${ }^{3}$ Megjegyzendô ugyanakkor, hogy mind Németországban, mind Magyarországon eddig számos részelemzés született, a szóban forgó cselekményeket azonban komplex módon még senki nem dolgozta fel, s így összehasonlítás sem születhetett. (Ennek egyik vélhetố oka az lehet, hogy az ilyen jellegú magyarországi cselekményekrôl nincs teljes adatbázis, sok ilyen tettrôl nem is értesül a hatóság, továbbá a jogalkotási és jogalkalmazási anomáliákból kifolyólag regisztrálásuk sem történik meg.) Vagyis eddig nem történt a témában tudományos összehasonlítás semmilyen szinten a két ország tekintetében, ${ }^{4}$ ami azért is sajnálatos, mert Németország az 1990-es évet követő átalakulás folyamán (az újraegyesítésnek köszönhetően) magában hordozta a posztkommunista országokra jellemzó nehézségeket, de egyúttal a fejlett nyugati országok jellemzôit is. Szinte egyszerre hasonlíthatjuk össze Magyarországot egy posztkommunista és egy fejlett állammal.

A téma a rasszista motiváció és az idegengyúlölet kérdéseivel függ össze, és érinti az ún. „gyúlölet-búncselekmények” problémáit is.

Egy régebbi elemzésben Ruud Koopmans kimutatta: a xenofóbiát illetôen NyugatEurópában sem arról van szó, hogy az etnikai kisebbségekhez tartozók vagy a bevándorlók száma egyenes arányban áll az idegenellenes erôszak növekedésével (Koopmans, 1995). Az efféle erôszakot inkább a politikai elit nyitottsága vagy zártsága, az etnikai kisebbségek diszkriminációjának problémája iránti érzékenysége, valamint a szélsôjobboldal politikai szervezeteinek elfogadottsága és/vagy sikerei befolyásolják. A politikailehetôség-struktúrák meghatározott szerepe még inkább jellemzó a posztkommunista társadalmakban. Németországban - amint arra több elemzés is felhívta a figyelmet ${ }^{5}$ - a 20. század végére váltak akuttá a török-muzulmán népesség integrációjával kapcsolatos problémák is.

Azok a magyarázatok, amelyek az erôszak-alkalmazás esélyét latolgatják a társadalomban, végsố soron a társadalmi struktúrához vezetnek vissza, a csoportviszonyok komplex hálózatának közvetítésével. Magyarország esetében a kommunista rendszer utáni átmenet struktúráiról van szó, amikor gyors és radikális folyamatok rendezik át a csoportok korábbi státuszviszonyait, új normák és legitimációs minták jelennek meg, amelyek próbára teszik a korábbi társadalmi és kulturális identitásokat. A státusuk relatív csökkenését érzékeló identitásukat vesztett, avagy nem megfelelôen kialakított csoportok számára a rasszista motivációjú kollektív erôszakban való részvétel valamiféle új kollektív identitás megerôsítését szolgálhatja az anonim társadalmi folyamatok okozta frusztrációk és anómia megoldásaként. Kérdés, hogy hasonló folyamatok hatnak-e Németországban? Mint ahogyan egy magyar politológus, Szabó Máté rámutat: Magyarországon azért gyanakodhatunk e tényezókre, vagyis arra, hogy ezek váltják ki a rasszista motivációjú erôszakot, mert a roma népcsoport korábban is, sôt évszázadok óta jelen volt az országban, és a bevándorlók száma még mindig elhanyagolhatónak mondható, mégis erôszakos xenofób cselekedetekkel találkozhatunk (Szabó, 1997). A rasszista motivációjú erôszakcselekmények vizsgálata során fontos elkülöníteni a közösség elleni izgatás, a közösség tagja elleni erôszak és a kifejezetten gyúlölet vezérelte búncselekmények szabályozását és eseteit. A magyar szakirodalomban ezt többen is 
tárgyalják, ${ }^{6}$ az ezzel kapcsolatos német szakirodalmat azonban itthon még nem dolgozták fel. A fenti témájú kutatáshoz azonban azt is meg kell vizsgálni, hogy miként dolgozza ki a német és a magyar állam a xenofób erốszakot tiltó jogszabályokat, s miként ültette át jogrendszerébe az európai és nemzetközi jogi irányelveket? Történtek- e közigazgatás-szervezési, illetôleg -átszervezési intézkedések, akár a xenofóbiával összefüggésben, akár a migrációhoz társuló integrációs törekvésekkel összefüggésben, létrehoztak-e új állami szerveket a probléma kezelésére, illetooleg módosították-e a létezô szervezetrendszer hatásköreit minderre tekintettel?

További kérdés a közigazgatási intézményrendszer alakulása és a szabályozás problémája, hiszen a magyar jogalkotás és joggyakorlat közismerten mintakövető, de - az elsó komolyabb elemzéseken túl ${ }^{7}$ - nem tisztázott, hogy milyen mintákat követ, vagy kellene követnie. Az elmúlt két évtizedben ugyanis a mindenkori magyar törvényhozó és végrehajtó hatalom, a kormány és a közigazgatás, valamint a politikai elit inkább a kontinentális-európai, azon belül pedig a német jogfelfogást és a német mintákat követte, amely sokkal tágabban fogalmazza meg a gyúlöletbeszéd és a gyúlölet-búncselekmény jogi definícióját, továbbá szigorú büntetések kilátásba helyezésével tiltja óket. Ezzel szemben az Alkotmánybíróság bevezette és következetesen alkalmazza az angolszász jogfelfogásban kialakult és meghonosodott „clear and present danger” elvét, amely a mindennapi bírósági gyakorlatba is beszivárgott, szúk keretek közé szorítva az ilyen jellegú tettek büntethetőségét. ${ }^{8}$ Leegyszerúsítve: a magyar politika túlnyomórészt büntetôjogi kérdésként kezeli az idegenellenességet, míg az Alkotmánybíróság a büntetôjog korlátozott alkalmazása mellett politikai konszenzus kialakítását és konzekvens érvényesítését javasolta. A magyarországi bíróságok gyakorlatából jól látható „eredmény” az, hogy ez a két, ellentétes felfogás nem jelent megoldást.

Egy további összehasonlítási szempont a következô: Németországban részletes és kiterjedt statisztikát vezetnek a gyúlölet-búncselekményekrôl (többek között ezt is megtudhatjuk a magyarországi gyúlölet-búncselekmények adatbázis-építését megcélzó Athena Intézet munkájából), és államilag - rendszeresen és pontosan - jelentést küldenek az EBESZ felé is. Ezzel több dolgot is elérnek: jelzik, hogy az állam kiemelkedő helyen kezeli a legkiszolgáltatottabb lakosainak védelmét, minden eszközzel küzdenek a negatív jelenségek ellen, és nem akarják elkendôzni azok létezését. Azaz: stabil konszenzus képét mutatják mind a polgáraik, mind a többi európai állam felé ezen a területen, ami egyben jelzés a szélsôségeseknek: erôszakosságukkal szemben nem lesz elnézó a hatalom. Magyarországon ezzel szemben a legnagyobb probléma a gyúlöletbúncselekményekkel kapcsolatban az, hogy sok ilyen tettről nem is értesül a hatóság (látencia), illetve ha a tudomására jut is, nem alkalmazzák a meglévô jogszabályokat.

A téma kapcsán az elemzésekben természetesen jelen van a jobboldali szélsôség problémája is. De hogyan nyilvánul meg ez konkrétan? Milyen magyarázatok vannak a jobboldali szélsôségesség megjelenésére? A témában európai vonatkozásban a hazai publicisztikában igen részletes elemzéseket ismerhetünk meg francia, görög és holland esettanulmányok kapcsán (Juhász-Krekó, 2012:17-22). A téma alaposabb elméleti elemzését Samuel Salzborn nyújtja. Salzborn munkája nemcsak a jobboldali szélsôségesség kutatásának központi vitáit tekinti át, de bemutatja ennek a világnézetét 
és ideológiáját, valamint fejlôdési irányait Németországban és Európában, valamint a szélsôségesség megnyilvánulási formáit is (Salzborn, 2015).

A téma további vizsgálata során elsôsorban a nyílt idegenellenesség formáira célszerú koncentrálni. Ahogyan Krekó Péter és Hunyadi Bulcsú is megállapítja: e téren Németországot és Magyarországot egy csoportba sorolják a hétköznapokban a szélsôségesek jelentette veszély szempontjából. Feltételezhetô ugyanakkor, hogy „a különbségek jelentôsek”, s ami még inkább szembetúnô: „eltérô a szélsôségességre adott társadalmi és állami reakció” is. „Németországban egyre fontosabbak a szélsôjobboldaliak kiugrását és társadalmi reintegrációját célzó kezdeményezések. Magyarországon hajlamosak vagyunk azt gondolni, hogy a szélsôjobboldallal kapcsolatos minden probléma nálunk a legsúlyosabb, ám ez közel sincs így. Németországban például, ahol az erôs szélsôjobboldali párt a világháború óta érdemben nem tudott megkapaszkodni a politikai életben, kifejezetten aktív és veszélyes, erôszakos szélsôjobboldali színtér múködik, körülbelül huszonötezer fố aktív részvételével. A német belügyminisztérium nemrég publikált jelentése szerint minden második extremista csoportban múködô aktivista kész tettleg is erôszakot elkövetni az általa képviselt célok érdekében. 2013-ban 473 rasszista és 45 antiszemita búncselekményt regisztráltak, ez pedig húszszázalékos emelkedés az előzô évihez képest” (Krekó-Hunyadi, 2014). Több publicisztikai írás arra következtet, hogy Magyarországon a szélsôjobboldal inkább (párt)politikai probléma, Németországban pedig inkább ez az erôszakos szélsôjobboldal jelenti a fenyegetést. A hírmorzsákból azt sem lehet egyértelmúen megállapítani, pedig ezt rendszerint feltételezzük, hogy a hatóságok minden szempontból jobban kezelnék a helyzetet, mint például Magyarországon. ${ }^{9}$

Hipotézisem mindezek mellett az, hogy az idegenellenes cselekmények strukturális összehasonlítása olyan eredményt hoz, amely tanulságos lehet a témában az állami beavatkozásra és szerepvállalásra nézve. Az e területen végzett elemzések feltehetóleg hasznosíthatók a magyar közigazgatás számára is, mind az idegenellenesség, mind a bevándorlási kérdés kezelése, az esetleges integrációs intézkedések kapcsán is. A migráció mellett ki kell térni a probléma történeti elóképeire és nagyobb történeti ívú kezelésére is. Ugyanis azt nemcsak feltételezhetjük, hanem tényként állíthatjuk, hogy amíg Magyarországon nem történt meg a 20. század egyik legnagyobb xenofób cselekedetének, a holokausztnak a feldolgozása, addig Németország ennek mintapéldájává vált, feltételezésem szerint az ehhez vezetô út az állam - jogalkotás és jogalkalmazás, törvényhozás és közigazgatás - helyes fellépésében és a társadalmi problémára adott helyes reakciójában rejlik.

Fontos kérdés, hogy a rasszista motivációjú erôszak a társadalomban szervezetlen tömegcselekvésként vagy szervezett mozgalmak tevékenységeként, szervezetek (pártok) akciójaként jelenik-e meg? Ugyanígy: ugyanaz a társadalmi-politikai konfliktus különbözố szinteken és formákban egyidejúleg jelen lehet a társadalom életében? Hogyan jelenik meg egyik és másik államban? Az állam maga is differenciált intézményrendszer, amelynek különbözô szektorai eltérôen viszonyulhatnak a szemben álló felekhez, így egy adott konfliktusban megjelenhet a kormányzat, egyes szakminisztériumok vagy akár a rendôrség „saját” politikája. 
A 19. és 20. századi állami politika számos konfliktusmegelőzô, -kezelô vagy -megoldó módszert alkalmazott. A nyílt idegenellenesség értelmezéséhez igen hasznos lehet egy ún. „xenofóbiaskála”, amelynek egyik végpontja a „propaganda”, a másik a „népirtás”. A kettô közötti fokozatok - például gyúlöletincidens, gyúlöletbeszéd, gyúlölet-búncselekmény stb. - részletes fogalmi kidolgozásra várnak. Ugyancsak kidolgozásra, majd elemzésre várnak azok a fogalmi kérdések, amelyek a migrációval és az integrációval járó társadalmi folyamatokkal és azok állami kezelésével kapcsolatosak, ideértve egyfelôl az asszimiláció, másfelôl a szegregáció kérdéseit is. Egy ilyen kutatás eredményei minden bizonnyal jól hasznosíthatók a közigazgatásra vonatkozó további elemzésekben, mind a migráció, mind a bevándorlás, mind pedig az integráció vonatkozásában.

\section{JEGYZETEK}

1 Az írás a KÖFOP 2.1.2-VEKOP-15-2016-00001 azonosító számú, „A jó kormányzást megalapozó közszolgálat-fejlesztés” elnevezésú kiemelt projekt keretében, a Nemzeti Közszolgálati Egyetem felkérésére készült.

2 A globális migráció következtében a legfrissebb kutatások az állami szerepvállalás tekintetében gyakran az integráció problémaköre körül forognak. Így például lásd Friedery, 2016.

3 Lásd például Kurthen, 1997; Bergmann, 1997; Erb, 1997.

4 Egy kisebb magyar kutatás ismert, amely azonban a témára vonatkozóan érdemben csupán a német tapasztalatokat mutatja be. Vö. Utasi, 2010. Továbbá az idegenellenességet tekintve Németországra vonatkozó részletes összehasonlító kutatás egészen a legutóbbi idôkig csak az országon belüli helyzet elemzésérôl született, azaz a nyugati és a keleti blokk idegenellenességével kapcsolatosan. Lásd Schroeder, 2003. A megismerhetô legújabb összehasonlító elemzések is az Amerikai Egyesült Államokkal hasonlítják össze a németországi helyzetet, lásd például Kahn, 2006.

5 Például Gamson-Meyer, 1996.

6 Lásd például Bencze, 2014.

7 Lásd például Balogh-Pap, 2012.

8 Ezt részletesen tárgyalja Dinók, 2013.

\section{FELHASZNÁLT IRODALOM}

Balogh Lídia - Pap András László (2012): A jog által láthatatlan? A gyúlölet-búncselekmények szabályozási kérdései és gyakorlati problémái. Fundamentum, 16. évf., 4. sz., 91-98.

Bencze Mátyás (2014): A gyúlölet-bûncselekmények és ítélkezési populizmus. Fundamentum, 18. évf., 1-2. sz., 129-139.

Bergmann, Werner (1997): Antisemitism and Xenophobia in Germany since Unification. In: Antisemitism and Xenophobia in Germany After Unification. Eds. Hermann Kurther, Werner Bergmann, Rainer Erb, Oxford University Press, New York, 39-87.

Dinók Henriett Éva (2013): A gyúlölet-búncselekmények, különösen a közösség tagja elleni erôszak kapcsán felmerülố jogalkalmazási nehézségek. Fundamentum, 17. évf., 4. sz., 93-103.

Erb, Rainer (1997): Public Responses to Antisemitism and Right-Wing Extremism. In: Antisemitism and Xenophobia in Germany After Unification. Eds. Hermann Kurther, Werner Bergmann, Rainer Erb, Oxford University Press, New York, 211-223.

Friedery Réka (2016): Migráció és integráció: a német modell. Acta Humana, 4. évf., 4. sz., $23-32$.

Gamson, William A. - Meyer, David S. (1996): Framing political opportunity. Comparative Perspectives on Social Movements. Eds. Doug McAdam et al., Cambridge University Press, New York, https://doi.org/ $10.1017 /$ cbo9780511803987.014. 
Juhász Attila - Krekó Péter (2012): Politikai stratégiák a szélsôjobboldallal szemben. Kutatási összefoglaló, Political Capital, 17-22.

Kahn, Robert A. (2006): Keresztégetés, holokauszttagadás és a gyúlöletbeszéd szabályozásának fejlôdése az Amerikai Egyesült Államokban és Németországban. In: A gyúlölet szabadsága - amerikai és európai perspektívák. Szerk.: Koltay András, Wolters Kluwer, Budapest, 71-108.

Koopmans, Ruud et al. (1995): New Social Movements in Western Europe. University of Minnesota Press, Minneapolis, https://doi.org/10.4324/9780203501115.

Krekó Péter - Hunyadi Bulcsú (2014): Van visszaút. Hogyan gyógyítható a szélsôjobb? Magyar Narancs, 45 . sz.

Kurthen, Hermann (1997): Antisemitism and Xenophobia in United Germany. How the Burden of the Past Affects the Present. In: Antisemitism and Xenophobia in Germany After Unification. Eds. Hermann Kurther, Werner Bergmann, Rainer Erb, Oxford University Press, New York, 21-38.

Salzborn, Samuel (2015): Rechtsextremismus. Erscheinungsformen und Erklärungsansätze. 2. Aufl. Nomos, Baden-Baden.

Schroeder, Klaus (2003): Rechtsextremismus und Jugendgewalt in Deutschland. Ein Ost-West Vergleich. Ferdinand Schöningh, Paderborn-München-Wien-Zürich.

Szabó Máté (1997): Erôszakos kirekesztés vagy multikulturális tolerancia. Politikatudományi Szemle, 6. évf., 1. sz., 55-97.

Utasi Judit (2010): Gyúlöletbûnözés - szélsôjobb. Kitekintés Németország tapasztalataira. Belügyi Szemle, 58. évf., 11. sz., 5-20. 